\title{
Progress in Palæontology.
}

H YABE and S. Endò (Sci. Rep. Tôhoku Uni., Sendai, Geology, vol. 5, p. 93, 1921) have reexamined the specimen believed to be a Sigillarian stem, found in Suruga Province by K. Fujii in 1915. While they suspend judgment on this specimen, they are now able to record the discovery of stems of Calamites by $\mathrm{S}$. Makabe in the province of Iwami. These are the first Palæozoic land-plants recorded from insular Japan. The Carboniferous beds with which they are associated are marine, and it seems unlikely that any considerable flora will be unearthed comparable to that known from the adjacent continent.

Zoning by Foraminifera received a new impetus from the division of the well-known genus Orbitoides into a restricted group and two other genera. When cut horizontally, the equatorial layer in these discoidal forms shows chambers of lozenge shape in Orbitoides, which is Cretaceous, of rectangular shape in Orthophragmina (Eocene), and of hexagonal shape in Lepidocyclina (Upper Eocene and Oligocene). C. W. Cooke and J. A. Cushman ("Orbitoid Foraminifera from Georgia and Florida," U.S. Geol. Surv., Prof. Paper 108-G) in I9I7 described forms of Orthophragmina, usually stellate, from the Ocala Limestone of the south-eastern States, and thus assigned to this horizon an Eocene age. In Prof. Paper $125^{-D}$, I920, $\mathrm{J}$. A. Cushman investigates and illustrates by bold photographs "The American Species of Orthophragmina and Lepidocyclina.". Many of these forms were described by the author in Iorg in Pub. 291 of the Carnegie Institution; but thirteen others are new, and the whole group will be of interest for comparison with those of India and other countries. From Japan, for instance, we receive H. Yabe's "Notes on two Foraminiferal Limestones from Borneo" (Sci. Rep. Tôhoku Univ., Geology, vol. 5, p. Ioo), with illustrations of flexed forms of Orthophragmina side by side with Assilina and Nummulites. Yabe also describes ( $p$. 97) four species, representing three genera, of arenaceous foraminifera that came to light on cleaning Japanese nummulites to which they were adherent. This opens a suggestive line of research.

T. W. Vaughan (U.S. Geol. Surv., Prof. Paper 98-T) uses the reef-coral fauna of Carrizo Creek, California, to show that in Pliocene times a renewed connection took place between the Atlantic and the Gulf of California across Central America. Owing to the formation of a land area from north to south, Pacific elements disappeared from the Atlantic fauna after the Upper Oligocene epoch. At Carrizo Creek, however, Atlantic forms occur in Pliocene strata, similar to those of Florida and the West Indies, and there is, curiously enough, no admixture of Pacific forms. The belt of Cainozoic limestone in Porto Rico, with its curious "pepino"' structure, has been mentioned recently in NATURE (vol. 105, p. I47). The New York Academy of Sciences now continues its scientific survey by issuing Bela Hubbard's report on "Tertiary Mollusca from the Lares District" ; these are mostly of Middle and Upper Oligocene age. Among other works on mollusca we may note the additions to our knowledge of fossil Unionidæe in the Indian region made by E. Vredenburg and B. Prashad (Rec. Geol. Surv. India, vol. $5 \mathrm{r}, \mathrm{pp} ., 368$ and $37 \mathrm{I}, \mathrm{192} \mathrm{r})$, since members of this family have hitherto been known only from the late Cretaceous intertrappean beds in the Peninsula and from the Lower Miocene of Baluchistan. Prashad's Lamellidens Vredenburgi is from the intertrappean beds of Narbada; it is the oldest known representative of this genus, which is one of the dominant members of the Unionida in the modern Indian fauna, and it is thus probably very near the point at which Lamellidens branched from Unio. In another recent part of the Records (vol. $5^{\mathrm{I}}$, pp. 66- $\left.5^{2}\right)$ E. Vredenburg reviews the whole family of the Cypræidæ, the earliest known members of which are the strongly differentiated genera Gisortia and Eocypræa in the Albian stage. He emphasises d'Orbigny's separation of Ovula, a delicate shell that probably existed before Eocene times, and would (p. 82) ally it to the Strombidæe rather than the Cypræidæ.

The Yorkshire Geological Society (Proc., I919-2o, p. 359) publishes the last work of the late Lt.-Col. Wheetton Hind, who was equally devoted to Carboniferous fossils and to his artillery in the field. Goniatites are here described from a zone lower than "any previously known in the British Carboniferous series, the Upper C Beds of Vaughan, and this record from Kniveton, Derbyshire, is worth making, though the species are not new. S. S. Buckman's fine work on "Type Ammonites" has been recently referred to in NATURE (vol, Io6, p Io3), and has now reached its twenty-eighth part. New names seem abundant and inevitable, but there is something magniloquent in the passage of Ammonites giganteus into Titanites titan. J. W. Tutcher's beautiful illustrations will console and guide curators who have the courage to start afresh on their collections.

P. E. Raymond's "Contribution to the Description of the Fauna of the Trenton Group" (Canada Geol. Surv., Museum Bull. 31, I921) contains a number of observations on cystidea. The photograph of four discoidal specimens of Isorophus in their natural position on the sea-floor is a pleasing picture of Ordovician times. The species figured, which is common at Ottawa, has hitherto been regarded as Agelacrinites Billingsi. Prof. Raymond has undertaken a far more ambitious piece of work in his monograph on "The Appendages, Anatomy, and Relationships of Trilobites." (Mem. Connecticut Acad. Arts and Sciences, vol. 7, I920, Newhaven, Conn., 6 dollars). This is dedicated to the memory of C. E. Beecher, whose numerous photographs of specimens showing appendages are here for the first time reproduced. Dr. Elvira Wood has rendered great assistance in her reconstructions of trilobites in their habit as they lived. We wish that Miss Woodward's sombre drawings of marine life in Palæozoic times could have found a place in the bibliography; Prof. Raymond, however, attributes to most trilobites a power of swimining that lifts them well above the level of H. M. Bernard's "browsing annelids" (Quart. Journ. Geol. Soc., vol. 5 $\mathrm{x}, \mathrm{p}$. 3.58). When we regard Burmeister's "View of an Asaphus cornigerus from below" (Ray Soc. ed., pl. 6, Fig. 8), with its attempt at the restoration of parts that were believed to be irrecoverable, we can imagine how this pioneer would have hailed the delicate drawings of Ceraurus (pl. 11), Triarthrus, and Neolenus in the present memoir. Burmeister emphasised the relationship of the trilobites to the phyllo. pod Branchipus: Bernard found their nearest ally in Apus; Raymond (p. 127) now observes that "the thoracic limbs of Apus must be looked upon as highly specialised instead of primitive." since the ancestra Branchipoda of Middle Cambrian times had simple biramous appendages. He believes (p. I46) that the higher crustacea are all derived from the trilobita

No. 27 I9 VOL. IO8] 
and that the ancestor of the latter was a pelagic arthropod with few segments, the crawling habit being a modification. The carapace may have been developed in consequence of this habit, and may at first have been unsegmented. "The numerous appendages arose at this stage, but their presence broke up the dorsal test into corresponding segments as swimming and crawling activity developed. The elongate worm-like character of some trilobites with many segments, such as Robergia of the Middle Ordovician, is thus held to be a secondary character ( $\mathrm{Pp}$. $\mathrm{I}_{3} 8$ and I5 I). Walcott's Marrella (p. I 5 ) from the Middle Cambrian is here handsomely restored, and so far no biramous appendages are known in connection with its head-shield. It is regarded (p. 143) as an already specialised link between the trilobites and the higher crustacea. Raymond's thoughtful and stimulating work' revives many memorable discussions, and it reverses accepted opinions for reasons that are simply stated. The details of Beecher's observations receive their fullest exposition and illustration from a pupil who has used them aptly as a basis for independent thought.

In the palæontology of early vertebrates even a footprint may count for much. Our minds are still obsessed by the mysterious impressions in Devonian strata to which Marsh assigned the name Thinopus. R. S. Lull's traces of Dromopus (?) Woodworthi, n. sp. (Amer. Journ. Sci., vol. 200, p. 234, I920), from an Upper Carboniferous shale in Massachusetts, are regarded by the author as possibly reptilian. It is bointed out that Williston's Isodectes Copei would have made an impression much like that already known as Dromopus agilis, Marsh; both these are Carboniferous, and Isodectes is already held to be a reptile. Chelonians are prominent in two recent papers. Eduardo H. Pacheco (Iberica, vol. 15, p. 328, 192I) gives photographs of the wonderful assemblage of gigantic turtles in an Upper Miocene flood-deposit in the Otero de Palencia. a hill rising from the tableland of Old Castile. Similar forms are known from the Miocene continental deposits of the neighbourhood, but the examples at Palencia, $I_{\frac{1}{2}}$ metres in diameter, seem to have been brought together by the sudden overflow of a river that entombed them in its sand. They resemble the living. but distinctly smaller, tortoises of the Galápagos Islands; the islands, by the by, received their name from these quaint inhabitants. Nine specimens have been utoparthed, and those in a fair state of preservation are destined for the museum in Madrid. C. W. Gilmore (U.S. Geol. Surv., Prof.
Paper 98-Q) describes well-preserved carapaces of turtles in the Ojo Alamo (late Cretaceous) sandstone of New Mexico. Associated with them are handsome skulls of the dinosaurian. Kritosaurus, a genus described by B. Brown in igro. The author in a second paper (Prof. Paper I03) introduces a newly found dinosaur, Brachyceratops, from beds of similar age in north-western Montana. The modelled restoration (pl. I) is founded on a skull and on the scattered remains of five individuals (compare pl. 4). It is represented with two stumpy horns, supraorbital and nasal, and a conspicuous bony frill extending backwards, but by no means so deterrent as that of Triceratops. The specimens are small, and may be immature. The length of the skull is $565 \mathrm{~mm}$. A few other reptilian remains are noticed in the paper.

The Marsh collection at Yale continues to supply material for a number of researches on Cainozoic vertebrata. R. S. Lull describes Oligocene camels (Amer. Journ. Sci., vol. 201, p. 392, 192r); E. L. Troxell (ibid., vol. 20o, pp. 243, 361, and $43 x, 1920$ ) examines the giant pigs styled entelodonts, and introduces the new genera Megachorus and Chærodon. The skull of the former has a length of $760 \mathrm{~mm}$. and singularly large plate-like dependent malar processes (p. 423). The canines of Chærodon are remarkably recurved ( $p .442)$. Both these genera are Oligocene. The same author (ibid., vol. 202, p. 4I, r92I) deals with the origins of the rhinoceros. He points out that in fossil forms the females are hornless, while the males have horns, and that the term Aceratherium, used for all hornless rhinoceroses, ceases to be of value. Other characters than those of the nasal bones indicate, however, that there is a group to which the name may be restricted in the Old World. Troxell lays much stress on Cænopus, of the American Middle and Upper Oligocene, as the ancestor of all later forms, including the modern genera of rhinoceroses. In connection with this point, the observations of H. Matsumoto are of interest (Sci. Rep. Tôhoku Univ., Sendai, Geology, vol. 5, p. 75, 192 I), since the author suggests the migration of the Miocene rhinoceros Teleoceras (pp. 8I and 88) from Palæarctic Asia to North America, together with other mammalian forms. He describes a new species from Japan, which he regards as more archetypal than the American Teleoceras. Returning to the Marsh collection, M. R. Thorpe proposes some new terms to facilitate the use of skull-measurements in his review of the Oligocene felidæ (Amer. Journ. Sci., vol. 200, p. 207, 1920).

\section{The Tea Industry.}

THE Production of Tea in the Empire and its Relation to the Tea Trade of the World " forms the subject of a comprehensive paper contributed by Mr. A. S. Judge to the Bulletin of the Imperial Institute (vol. 18, No. 4). The paper gives an interesting survey of the spread of tea-drinking in different countries, with particulars of the condition of the industry in all tea-producing areas.

Fifty years ago China and Japan produced practically all the tea consumed in the world; twenty years later, in 1890, India and Ceylon were seriously challenging China's monopoly, until at the present time they produce more than two-thirds of all the tea which enters the world's commerce, while their most serious competitor is Java, in which country tea can be produced more cheaply than in either India or Ceylon. At the beginning of 1919 prices in London for all grades of tea were good and stocks in the NO. 27 I9, VOL. IO87
United Kingdom were not excessive, but apparently trade had been disorganised by the war and by Government control, and since none of the dangersignals pointing to over-production were raised, the plantations in the British and Dutch East Indies produced tea to their full capacity. The Russian market, which had been taking $100,000,000 \mathrm{lb}$. of plantation tea yearly, was lost, and large stocks began to accumulate, until in the middle of I92o the actual situation was realised and there followed a break in prices for all the lower grades, which have since been selling below the economic value. There is no question regarding the soundness and ultimate prosperity of the Indian and Ceylon tea industries, but the immediate outlook for many estates is very critical, particularly those estates which produce mainly medium-grade teas.

It is to the common interests of both the producer and the consumer that the tea industry should be 